\title{
Relationship of Nursing Students Stress and Their Personal Response to Stress in Learning Environment
}

\author{
Saima Noureen* Muhammad Hussain Muhammad Afzal Syed Amir Gilani \\ Lahore School of Nursing, The University of Lahore, Lahore, Pakistan \\ Faculty of Allied Health Sciences, The University of Lahore, Pakistan
}

\begin{abstract}
Stressors are overwhelming and volatile trials that can modify over normal response to everyday events. The stress responses are reaction to the strains and variations of life both optimistic and undesirable. Stress responses may have physical, mental, emotional and behavioral sign. Nursing students have many stressors in their learning environment which effects their performance and quality of care.Methods: A descriptive correlational study was conducted in Government College of Nursing in Lahore. Data was gathered by nursing students of $3^{\text {rd }}$ and $4^{\text {th }}$ year of BSN and diploma nursing. Questionnaire which was used in this study was perceived stress scale and Physiopsycho-socio response scale developed by Sheu et al. Data was analyses by SPSS and using Pearson correlation test to see the relationship between stress and stress responses of nursing students.Results: Results shows significant correlation between the level of stress and stress response in students. Pearson correlation value is .594 and $p$ value is .000 on 0.05 level of confidence interval which shows significance of results.Conclusions: The correlational study was done in Government College of Nursing in Lahore. The study explores the level of stress in nursing students and their personal responses to stress in learning environment. It is concluded that if the stress level in nursing students reduce it can be helpful for the organization to improve the quality care of patient.
\end{abstract}

Keywords: Stress, Nursing students, Stress level, Stress responses

DOI: $10.7176 / \mathrm{JHMN} / 62-01$

Publication date:May $31^{\text {st }} 2019$

\section{Introduction}

Nursing profession is one of the most important profession in the world. Nurses helps the patient to recover and cares them for their wellbeing. They are supporters and health educators for patients, families and communities. Nurses duties have a great responsibility in any environment and they face many challenges. Due to these challenges nursing student suffer with stress in clinical settings. It might be possible the stress during clinical learning must be due to different stressors like lack of professional knowledge, clinical skill, assignment workload, fear of handling patient and peer pressure etc. Numerous scholars revealed that nurses face trouble in their clinical condition which results in burnout, depression and resting issue. Consequently, nursing students should be set up so as to face such difficult job and prepared them to cope with stress (Ismaile, 2017).

During clinical learning nursing students have stress due to various causes like adjustment in new wards, working with new peoples, interaction with new technologies and procedures. As study show Stress is a physiological reaction that impacts the intellectual, emotional, conduct, and social segments. It additionally includes the adjustment of the life form, the adapting assets, and environment (Pulido-Criollo, Cueto-Escobedo, \& Guillén-Ruiz, 2017)

Nursing education is an important part of clinical learning. During clinical learning nursing students face many stressors like lack of professional knowledge, teacher's behavior, assignments and workload. Identifying the stressors of nursing students can improve the competencies of the students in clinical practices. Studies shows that stressor for nursing students incorporates peer pressure, educators or parent's desires, assignments, examinations, outstanding task at hand. Stress of nursing students may include clinical assignments, move obligation, fear of managing patients, relatives and other professional services experts, fear of taking care of bio restorative hardware and specialized progressions (Nirmala \& Suni, 2016).

When entering into the clinical practices with lack of theoretical knowledge nursing student cannot be performed their professional duties efficiently and it can be a source of stress for nursing students. Nursing students lack of theoretical knowledge may cause low confidence and decreased their clinical competencies. Before entering into the clinical practice nursing student should have enough knowledge, as indicated in studies lack of knowledge in theory and practice is one of the problem of nurses. Therefore, when students enter the clinical environment, it is necessary that they are theoretically and practically prepared as they take tests and give care in the skill lab (Jamshidi, Molazem, Sharif, Torabizadeh, \& Najafi Kalyani, 2016).

However, For the preparation of skill full nurses it is necessary to organize the best classroom environment in which they can easily learn about their competencies. During classroom period nursing student have mostly stressed due to excessive assignment, increased assignments might be proved great stressor in nursing students. Many study shows during clinical learning, assignments and workload is the most common stress to students; nursing students mostly used transference coping strategy for their stress (Zhao, Lei, He, Gu, \& Li, 2015). 
However, academic stress can also cause bad performance of students in school. In the long term, stress can even affect the abilities of the students because stress might be generating a confused atmosphere for them. Due to stress, most students easily become anxious about what they have been taught. Therefore, the effect of stress lead poor academic performance in schools (Umar, 2019)

Therefore, stress over academic performance can cause stress indications, for example, uneasiness, a sleeping disorder or changes in your craving and by and large state of mind. The fear of examinations creates stress among students (Umar, 2019).

Clinical stress of nursing students may include low confidence to deal with patient and their families, lack of experience and poor judgement skills and less knowledge how to deal with patient problems and expectations and also the students may have stress due to role change from students to staff. Researchers says many students did not have sufficient information to care of patient at the bedside and providing care to the patients is thoughtprovoking for them. Insufficiently developed communication skills sometimes cause disruption in providing care for patients. Lack of practical skills in caring for patients is big p a concern of many students in the clinical area. Therefore, students became distressed in dealing with new experiences while providing care to patient. Such reactions have a significant effect on their learning process (Jamshidi et al., 2016).

Moreover, stress of clinical environment may include stress from new circumstances and ward facilities and patient condition change and unfamiliar with new techniques. Studies shows parts of the clinical setting may cause differing degrees of stress in nursing students. Clinical sources that were distinguished as most distressing incorporate managing new circumstances, figuring out how to apply clinical methodology and overseeing specialized instruments, among others (Wallace, Bourke, Tormoehlen, \& Poe-Greskamp, 2015).

Nursing students stress may be due to discrimination of teachers and staff, nursing students became stressed when see the difference between theory and practice because in clinical setting the practices are different from theory. Student suffer from fear and anxiety when not properly treated by teachers and medical staff. As studies show students face some problems during clinical setting due to interaction with instructors, patients, and department personnel. Many students believed that during practices the way in which teacher instruct and evaluate the students have great impact on their learning (Jamshidi et al., 2016)

Recently graduated nurses who meet, socialize and share encounters have described supporting each other's capacity to adapt to stress. Peer learning includes people in a comparable circumstance gaining from and with one another through association (Pålsson, Engström, Leo Swenne, \& Mårtensson, 2018).

However clinical experience prepares the nursing students to get familiar with their work environment. It encourages the students to enhance their basic reasoning to relate and welcome the basis of nursing systems. It additionally encouraging them to organize the requirements and issues of the patient to design and give proper care (Vijayananthan, Premkumar, Jesudoss, \& Rajan, 2016).

Nursing students' responses to stress may include anxiety, fear of handling patient, apprehension, fear of discrimination by teacher and staff. In the university the most important stressor of nursing student is assignment workload included with peer pressure and discrimination by teachers. Researchers says that nursing students' reactions to stress in clinical site is different from one individual then onto the next. Stress cause destructive consequences for their physical and mental wellbeing. Physical responses include increased heart rate, headaches, stomach and sleep pattern disorders and elevated blood pressure. Psychological responses include anxiety, mood swinging, panic attacks, and depression. Also, they may feel being solitary, hopeless, nervous, and experiencing memory problems. Moreover, stress may cause serious problems such as smoking, drug addiction, and suicide. Students' stress can be viewed intellectually in their inability to finish their homework on time, failure to solve complications, decline in their results (Elsayes \& Obied, 2018).

\section{1: AIMS OF THE STUDY}

To evaluate the relationship between stress level and responses to stress among student nurses

\section{2: SIGNIFICANCE OF THE STUDY}

This investigation gives standard data about nursing student stressors and stress responses. Effective adapting methodologies may help students to perform better and furthermore can help in relieving students stress. On behalf of this research information clinical teachers and decision maker will might be measures the stressor of nursing students and overcome these stressors through conducted workshop, seminars and teaching session on coping strategies which will be helpful for the students to cope with stress. This study will add the knowledge to the clinical teachers and managers by suggesting that increased use of the clinical teaching behaviors and coping strategies might be contributing to a more positive outcome of the clinical experience by students. The results of current study will also helpful for the nursing students to minimize the stressors by using strategies like discussion with teachers, mentor and staff which help to achieve their goals in the clinical setting and it will improve the quality of patient care and reduce the stress related to clinical learning. After conducting this research, data will be presented with higher authority of association to fulfill their gaps by organizing the workshops. This will also 
helpful for me as a nurse to integrate these effective clinical behaviors in my future practice.

\section{LITERATURE SEARCH}

An investigation directed at Department of nursing, college of Paradeniya exhibits that there is a contrary relationship among stress and absence of expert information and aptitudes. Results demonstrate that most of the respondents revealed gentle to amazingly serious indications of depression $(51.1 \%)$, nervousness $(59.8 \%)$ and stress $(82.6 \%)$. It demonstrated a noteworthy positive connection among depression and uneasiness $(\mathrm{r}=.689, \mathrm{p}$ $<.001)$, misery and stress $(r=.785, \mathrm{p}<.001)$ and tension and stress $(\mathrm{r}=.763, \mathrm{p}<.001)$. The variables related with despondency were age, scholarly year of the students, fulfillment with the nursing program, physical prosperity components and self-evaluated psychological wellness; the elements related with tension were age, self-appraised physical wellbeing and self-evaluated emotional well-being and the elements related with pressure were conceivable stressors, self-appraised physical wellbeing and self-appraised psychological wellness (Rathnayake \& Ekanayaka, 2016).

Â Study was conducted in two medical departments; surgical wards; outpatient clinic and day care unit at King Abdul Aziz University Hospital to assess the student's perception related to stress in clinical learning. Results shows that two- third of the studied sample $69.15 \%$ complain stress because of unfamiliar with medical history and terms, and $86.38 \%$ were worried about poor grades, while approximately two- third $(63.19 \%)$ of the studied sample expressing that dullness and stubborn clinical exercise affect their personal/social life. However, 70.32\% $70.32 \%$ were anxious because they feel that they were unable to reach their teacher and staff expectations in the clinical training, while approximately two- third of them (66\%) mentioned that they felt depress and miserable if they received negative criticism from their teachers and $71.49 \%$ were seeing a discrepancy between theory and practice (Hakami, Mahran, \& El-senany, 2017).

A correlational investigation of nurses who were worked in private and public unit led in 2013 in Greece exposed that, Nursing is viewed as a strenuous action. Although past research has filed that stress impacts nursing students' prosperity in association with individual fulfillment, the connection among stress and caring behavior remains decently unexamined. Studies demonstrates that stressful factors components were those that were identified with death and dying the bucket $(\mathrm{m}=2.65 ; \mathrm{SD}=0.76)$ and those related with patient and family $(\mathrm{m}=$ 2.56; $\mathrm{SD}=0.88)$ Highest mean estimations of stress was "Proficient information and aptitude" $(\mathrm{m}=5.07 ; \mathrm{SD}=$ $0.73)$ and in "Affirmation of human nearness" $(m=4.90 ; \mathrm{SD}=0.76)$ (Sarafis et al., 2016).

A subjective report conducted to evaluate the student observation about their clinical experience showed that the nursing students were not completely happy with their clinical experience. They experienced anxiety and stress and brought recommendations to improve their clinical learning. Nursing students needs a cordial clinical condition for their dynamic learning. They depicted that they should be treated as grown-ups and need to concentrate on learning the expert job of nurses. They need to adapt more ability situated learning in the clinical zone (Vijayananthan et al., 2016).

A cross-sectional study analyzes the stress, adapting methodology, self-adequacy just as the anticipating impacts of stress and self-viability on recurrence of utilization of adapting procedure of nursing students in China. The most well-known stressor seen by students was assignments and outstanding task at hand $($ Mean $=2.20)$ trailed by worry from companions and day by day life (Mean $=2.10)$ and dealing with patients. The least stressor was absence of expert abilities. The most widely recognized adapting conduct utilized by nursing students was transference, trailed by remaining idealistic and critical thinking. The least every now and again utilized adapting methodology was avoidance (Zhao et al., 2015).

A similar expressive research configuration was utilized to evaluate connection between perceived stress and psychological conduct treatment in nurses of Philippines which indicates huge positive relationships between the general PSS mean score and "transference" $(\mathrm{p}=0.181)$ and 'avoidance" factors. Moreover, measurably huge negative connections were recognized between the general PSS mean score and "stay optimistic" $(p=0.183)$ and "critical thinking" ( $p=0.074$ ) factors. Overall, the PSS mean score corresponded altogether with the absolute CBI mean score $(p<0.001)$. By fortifying nursing students' certain methods for managing stress, it may empower them to all the more promptly oversee stressors and achieve most noteworthy clinical learning. Positive adapting lessens feelings of anxiety in nursing understudies as well as conservatives the impacts of weight on their physiological and mental prosperity (Labrague, McEnroe-Petitte, Leocadio, Van Bogaert, \& Cummings, 2018)

A descriptive correlational investigation found factually critical positive connections between both staff strong practices and caring practices and their influence on the student's choice. Afterward, an inspiring open door is available for nursing teachers to utilize steady and caring practices that can significantly affect academic progression in nursing This study found statistically significant positive relations $(\mathrm{p}<.01)$ between both facultysupportive behaviors and caring behaviors and their effect on the student's choice to attend graduate school (White, 2018).

A descriptive cross sectional study showed which held in Sir Ganga Ram and Mayo hospital Lahore Pakistan to assess the association between clinical faculty behavior and student learning .The Overall result shows that $89 \%$ 
of teaching behavior have string and positive relationship with students learning and it affect the students learning significantly and this is concluded from this study that the behaviors of clinical teaching faculty have positive relationship and influence students learning (Ramzan, Kousar, Chanda Jabeen, \& Gilani, 2017).

An investigation conducted in 2013 in Gauteng area in private and public clinics to evaluate the connection between business related stress, burnout, work fulfillment and general health of nurses. Finding of the examination demonstrates that staff issues are best connected with physical manifestations, social dysfunction and extreme burdensome indications, clarifying 7\%,11\% and 5\% change, individually. Quiet consideration is best connected with nervousness and a sleeping disorder clarifying $11 \%$ fluctuation. All affiliations are huge $(\mathrm{p}<0.05)$. Both patient consideration and staff issues are best connected with general wellbeing (Khamisa, Oldenburg, Peltzer, \& Ilic, 2015).

A study conducted to measure the perception of nursing students associated to clinical experience in nursing students of Midwestern University. Results of the study show that students were worried by incivility by healthcare staff and educators, irregularities and time imperatives. Research proposes that stress can meddle with learning. It is critical to decide reasons for stress so instructors can diminish pressure and improve students learning in clinical learning condition (Wallace et al., 2015).

A study directed in nursing school Thailand and findings demonstrated that biofeedback essentially decreased uneasiness and kept up feelings of anxiety in nursing students. Care reflection comparatively diminished tension, while likewise essentially bringing down feelings of anxiety. The biofeedback bunch showed critical decrease in tension dimensions among the three gatherings at post intervention A noteworthy lessening was found in the contemplation group from preintervention $(\mathrm{M}=25.45, \mathrm{SD}=7.80)$ to post intervention $(\mathrm{M}=21.28, \mathrm{SD}=6.95)$ in State Anxiety Scale scores $(F 1,28]=14.36, p=0.001,2=0.34)$. So also, the mean preintervention State Anxiety Scale score $(M=22.69, \mathrm{SD}=8.26)$ decreased altogether at post intervention $(\mathrm{M}=17.69, \mathrm{SD}=7.74)$ in the biofeedback gathering $\left(\mathrm{F}[1,28]=8.89, \mathrm{p}=0.006, \_2=0.24\right.$ (Ratanasiripong, Park, Ratanasiripong, \& Kathalae, 2015).

\section{METHODS}

\section{1: SETTING}

Research was conducted in Allama Iqbal Medical College at Jinnah Hospital Lahore.

\section{2: RESEARCH DESIGN}

A descriptive correlational study design was use in this study.

\section{3: POPULATION}

The target population of this study was the nursing students of Allama Iqbal Medical College of at Jinnah Hospital Lahore

\section{4: SAMPLING}

Randomized sampling technique was used.

\section{5: RESEARCH INSTRUMENT}

Data was collected from the nursing students by a questionnaire.

\section{6: DATA GATHERING PROCEDURE}

Questionnaire used in this study consisted of three parts:

Demographic part consists of age, gender, year level, family monthly income, hours spent in study and hours spent in sleep. Second part of the questionnaire was consisted of 29 item lickert scale with 6 subscales developed by Sheu et al 2002 on perceived stress scale, reliability of the questionnaire Chronbach alpha which was $.947 .3^{\text {rd }}$ part of the questionnaire was consisted of 21 item lickert scale with three subscales on Physio-Psycho-Socio responses with Chronbach alpha value .976. The Chronbach alpha value is more .7 which shows the consistency of data (Taber, 2018).

\section{7: ANALYZE DATA}

The data was calculated by SPSS version 25. Descriptive statistics used contain; percentage, mean, and frequency. Pearson's correlation coefficient will be used to assessment of the relations between stress level, and stress response. A p-value of equal to or less than 0.05 was well thought-out statistically significant.

\section{8: STUDY TIMELINE}

Study was conducted from 3-02.2019 to 20.04.2019. 


\section{9: Sample size}

In this study the sample size was 114 nursing students, sample size determined by Slovin 1960

formula (Khalil, Majeed, Bio \& Gilani, 2017)

$$
\begin{aligned}
& \mathrm{n}=\mathrm{N} / 1+\mathrm{N}(\mathrm{e}) 2 \\
& \mathrm{n}=160 / 1+160(0.05) 2 \\
& \mathrm{n}=160 / 1+160(0.0025) \\
& \mathrm{n}=160 / 1+0.4 \\
& \mathrm{n}=160 / 1.4 \\
& \mathrm{n}=114
\end{aligned}
$$

\subsection{0: ETHICAL CONSIDERATION}

The rules of the ethical committee of university of Lahore will be followed

- Written up-to-date permission letter attached and informed to all participants.

- All evidence and data collection will be reserved.

- During study participants will remain unidentified.

- The subjects will be knowledgeable and there are no harmful effects of the study.

- Participant will be informed that they will be left the study at any time during process.

- Data will be kept confidential and in lock.

\section{RESULTS}

This chapter consists of four sections in which section one indicates frequency and percentage of demographic data, Section 2 show the mean and standard deviation of perceived stress and PPSRS scales and section 3 described correlation of the variables.

\section{Table: 1}

\begin{tabular}{|l|c|c|}
\hline & Characteristics & $\mathbf{N \%}$ \\
\hline Gender & Female & $114(100 \%)$ \\
\hline Age & $18-20$ yrs. & $32(28.1 \%)$ \\
& $21-23$ yrs. & $54(47.4 \%)$ \\
\hline Academic & $24-26$ yrs. & $28(23.7 \%)$ \\
Program & BSN & $54(47.4 \%)$ \\
\hline Academic & Diploma Nursing & $60(52.6 \%)$ \\
Year & $3^{\text {rd }}$ Year & $65(55.3 \%)$ \\
Family & $4^{\text {th }}$ Year & $49(43 \%)$ \\
Monthly & $20000-40000$ PKR & $30(26.3 \%)$ \\
Income & $41000-60000$ PKR & $37(32.5 \%)$ \\
& $61000-80000$ PKR & $24(21.1 \%)$ \\
\hline Hours spent in & More than above & $23(20.2 \%)$ \\
studying & less than 2 hours & $17(14.9 \%)$ \\
& $3-4$ hours & $39(34.2 \%)$ \\
& $5-6$ hours & $29(25.4 \%)$ \\
Hours spent in & More than 7 hours & $29(25.4 \%)$ \\
sleep & less than 2 hours & $5(4.4 \%)$ \\
& $3-4$ hours & $28(24.6 \%)$ \\
& $5-6$ hours & $58(50.9 \%)$ \\
\hline
\end{tabular}

\section{Table 1: shows the frequency and percentage of demographic data}

One hundred and seventeen student nurses were participated in this study in which 54(47.4\%) BSN and 60 $(52.6 \%)$ diploma nursing students of $3^{\text {rd }}$ year $63(55.3 \%)$ and $4^{\text {th }}$ year $49(43.0 \%)$. All students were female age between 18-20 was 32 (28.1\%),21-23 was 54 (47.4\%) and 24-26 was 28 (23.3\%). Students $37(32.5 \%)$ belongs to the families with monthly income range of 41000-60000. Most students 39 (34.2\%) spent 3-4 hours in study,29 (25.4\%) spent 5-6 hours and more than 7 hours in study. Students 58(50.9\%) who were sleep 5-6 hours in a day. 


\section{Section: 2}

Table: 2

\begin{tabular}{|l|r|r|r|}
\hline Variables & Mean & Standard. Deviation & $\mathrm{N}$ \\
\hline Emotional Symptoms & 2.0752 & .88721 & 114 \\
\hline Social behavioral Symptoms & 2.0073 & .98599 & 114 \\
\hline Physical Symptoms & 1.9825 & .94232 & .79626 \\
\hline Grand Mean & 2.0205 & .796 & 114 \\
\hline
\end{tabular}

Table 2: Shows the mean and standard deviation of PPSRS

Table depict the mean and standard deviation of the stress responses among nursing students which explain the emotional symptoms of students with mean of 2.0752 and standard deviation .88721 ,Social behaviour system mean 2.0073 and standard deviation .98599 and physical symptoms mean 1.9825 and standard deviation .94232.Generally students shows emotional symptoms in reaction of stress so physio-psycho-social health of students was overall good. The grand mean of PPSRS was 2.0205 and standard deviation .79626 which shows the good health status.

Figure: 1

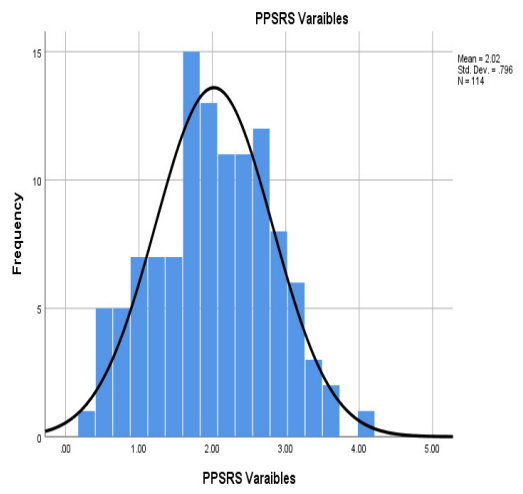

Figure 1 shows the normal distribution of PPSRS scale

Table: 3

\begin{tabular}{|l|r|r|r|}
\hline \multicolumn{1}{|l|}{ Descriptive Statistics of PSS Scale } & Std. Deviation & $\mathrm{N}$ \\
\hline $\begin{array}{l}\text { Stress from lack of professional knowledge } \\
\text { and skills }\end{array}$ & 1.7018 & 1.11605 & 114 \\
\hline Stress from assignment and workload & & .83336 & .80949 \\
\hline Stress from taking care of patients & 2.5140 & .88310 & 114 \\
\hline Stress from clinical environment & 1.8487 & .77653 & 114 \\
\hline Stress from teachers and nursing staff & 1.9708 & .73191 & 114 \\
\hline Stress from peers and daily life & 2.3114 & .62013 & 114 \\
\hline Grand Mean & 2.1579 & & 114 \\
\hline
\end{tabular}

Table 3: indicate the mean and standard deviation of the PSS Scale

Table showed the mean and standard deviation of the respondent stressor during learning which indicate that most common stressor of learning environment in nursing students was stress from assignment and work load with the mean (2.5140) and standard deviation (.83335),stress from teachers and nursing staff with the mean of (2.3114)and standard deviation(.77653),stress from peer and daily life mean(2.1579)and standard deviation(.73191) and other stressors include stress from lack of professional knowledge and skills with the mean of (1.7018) and standard deviation(1.11605),stress from taking care of patient mean(1.8487)and standard deviation (.80949) and stress from clinical learning environment mean (1.9708)and standard deviation (.88310).grand mean of PSS scale was 2.0992 and standard deviation .62013 which shows the moderate stress 
Figure: 2

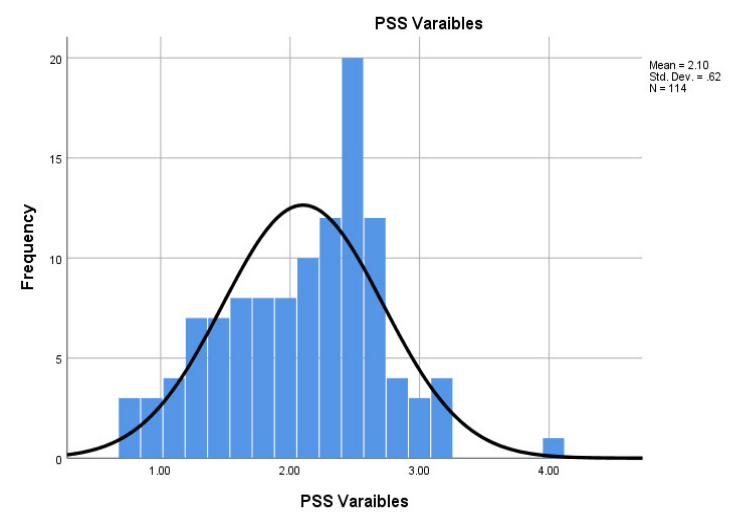

Figure 2 shows the distribution of PPSRS scale

Table: 4

NURSING STUDENTS STRESSORS IN LEARNING ENVIRONMENT

\begin{tabular}{|c|c|c|c|c|c|c|}
\hline $\begin{array}{l}\text { S. } \\
\text { No }\end{array}$ & Statement & Never & $\begin{array}{l}\text { Almost } \\
\text { Never }\end{array}$ & Sometimes & $\begin{array}{l}\text { Fairly } \\
\text { Often }\end{array}$ & $\begin{array}{l}\text { Very } \\
\text { often }\end{array}$ \\
\hline \multirow[t]{4}{*}{1} & $\begin{array}{l}\text { Stress from lack of professional knowledge and } \\
\text { skill }\end{array}$ & & & & & \\
\hline & $\begin{array}{l}\text { Unfamiliar with medical history and } \\
\text { terms }\end{array}$ & $24.6 \%$ & $21.1 \%$ & $31.6 \%$ & $14.9 \%$ & $7.9 \%$ \\
\hline & Unfamiliar with professional nursing skills & $24.6 \%$ & $21.1 \%$ & $28.1 \%$ & $19.3 \%$ & $7.0 \%$ \\
\hline & $\begin{array}{l}\text { Unfamiliar with patients' diagnoses and } \\
\text { treatments }\end{array}$ & $23.7 \%$ & $14.9 \%$ & $24.6 \%$ & $24.6 \%$ & $12.3 \%$ \\
\hline \multirow[t]{6}{*}{2} & Stress from assignments and workload & & & & & \\
\hline & Worry about poor grades & $8.8 \%$ & $7.9 \%$ & $20.2 \%$ & $26.3 \%$ & $36.8 \%$ \\
\hline & $\begin{array}{l}\text { Pressure from the nature and quality of clinical } \\
\text { practice }\end{array}$ & $3.5 \%$ & $5.3 \%$ & $36.0 \%$ & $32.5 \%$ & $22.8 \%$ \\
\hline & $\begin{array}{l}\text { Feelings that performance does not meet teachers' } \\
\text { expectations }\end{array}$ & $3.5 \%$ & $12.3 \%$ & $38.6 \%$ & $30.7 \%$ & $14.9 \%$ \\
\hline & $\begin{array}{l}\text { Feelings that dull and inflexible clinical practice } \\
\text { affect family/social life }\end{array}$ & $7.9 \%$ & $7.9 \%$ & $43.9 \%$ & $23.7 \%$ & $16.7 \%$ \\
\hline & $\begin{array}{l}\text { Feelings that the demands of clinical practice } \\
\text { exceed physical and emotional endurance }\end{array}$ & $4.4 \%$ & $4.4 \%$ & $35.1 \%$ & $36.0 \%$ & $13.2 \%$ \\
\hline \multirow[t]{9}{*}{3} & Stress from taking care of patients & & & & & \\
\hline & $\begin{array}{l}\text { Lack of experience and ability in providing } \\
\text { nursing care and in making judgment }\end{array}$ & $12.3 \%$ & $18.4 \%$ & $36.8 \%$ & $21.1 \%$ & $11.4 \%$ \\
\hline & $\begin{array}{l}\text { Not knowing how to help patients with physio- } \\
\text { psycho-social problems }\end{array}$ & $16.7 \%$ & $17.5 \%$ & $39.5 \%$ & $17.5 \%$ & $8.8 \%$ \\
\hline & Unable to reach expectations & $14.0 \%$ & $14.0 \%$ & $43.0 \%$ & $21.1 \%$ & $7.9 \%$ \\
\hline & $\begin{array}{l}\text { Unable to provide appropriate responses to } \\
\text { doctors', teachers' and patients' questions }\end{array}$ & $12.3 \%$ & $21.9 \%$ & $35.1 \%$ & $24.6 \%$ & $6.1 \%$ \\
\hline & $\begin{array}{l}\text { Worry about not being trusted or accepted by } \\
\text { patients or their families }\end{array}$ & $10.5 \%$ & $24.6 \%$ & $41.2 \%$ & $15.8 \%$ & $7.9 \%$ \\
\hline & Unable to provide patients with good nursing care & $17.5 \%$ & $25.4 \%$ & $28.1 \%$ & $23.7 \%$ & $5.3 \%$ \\
\hline & Not knowing how to communicate with patients & $21.9 \%$ & $27.2 \%$ & $30.7 \%$ & $16.7 \%$ & $3.5 \%$ \\
\hline & $\begin{array}{l}\text { Difficulties in changing from the role of a student } \\
\text { to that of a nurse }\end{array}$ & $16.7 \%$ & $17.5 \%$ & $29.8 \%$ & $24.6 \%$ & $11.4 \%$ \\
\hline \multirow[t]{4}{*}{4} & $\begin{array}{l}\text { Stress from clinical } \\
\text { environment }\end{array}$ & & & & & \\
\hline & $\begin{array}{l}\text { Feelings of stress in the environment where } \\
\text { clinical practice takes place }\end{array}$ & $13.2 \%$ & $7.9 \%$ & $50.9 \%$ & $19.3 \%$ & $8.8 \%$ \\
\hline & Unfamiliarity with ward facilities. & $14.0 \%$ & $15.8 \%$ & $44.7 \%$ & $16.7 \%$ & $8.8 \%$ \\
\hline & $\begin{array}{l}\text { Feelings of stress from rapid changes in a } \\
\text { patient's condition }\end{array}$ & $7.9 \%$ & $19.3 \%$ & $48.2 \%$ & $15.8 \%$ & $8.8 \%$ \\
\hline
\end{tabular}




\begin{tabular}{|c|l|c|c|c|c|c|}
\hline $\begin{array}{c}\text { S. } \\
\text { No }\end{array}$ & Statement & Never & $\begin{array}{c}\text { Almost } \\
\text { Never }\end{array}$ & Sometimes & $\begin{array}{c}\text { Fairly } \\
\text { Often }\end{array}$ & $\begin{array}{c}\text { Very } \\
\text { often }\end{array}$ \\
\hline 5 & Stress from teachers and nursing staff & & & & & \\
\hline & Seeing a discrepancy between theory and practice & $7.0 \%$ & $14.9 \%$ & $32.5 \%$ & $31.6 \%$ & $14.0 \%$ \\
\hline $\begin{array}{l}\text { Not knowing how to discuss a patient's illness } \\
\text { with teachers or medical and nursing personnel }\end{array}$ & $12.3 \%$ & $16.7 \%$ & $38.6 \%$ & $19.3 \%$ & $13.2 \%$ \\
\hline $\begin{array}{l}\text { Feelings of stress when a teacher's instruction is } \\
\text { different from expectations }\end{array}$ & $8.8 \%$ & $12.3 \%$ & $32.5 \%$ & $30.7 \%$ & $15.8 \%$ \\
\hline $\begin{array}{l}\text { Medical personnel lacking empathy and } \\
\text { willingness to help }\end{array}$ & $7.0 \%$ & $11.4 \%$ & $37.7 \%$ & $30.7 \%$ & $13.2 \%$ \\
\hline $\begin{array}{l}\text { Feelings that teachers do not evaluate students } \\
\text { fairly }\end{array}$ & $6.1 \%$ & $8.8 \%$ & $36.0 \%$ & $28.1 \%$ & $21.1 \%$ \\
\hline 6 & Lack of care and guidance from teachers & $6.1 \%$ & $13.2 \%$ & $31.6 \%$ & $34.2 \%$ & $14.9 \%$ \\
\hline & $\begin{array}{l}\text { Expers from peers and daily life } \\
\text { and clinical practice }\end{array}$ & $7.0 \%$ & $14.9 \%$ & $44.7 \%$ & $23.7 \%$ & $9.6 \%$ \\
\hline & $\begin{array}{l}\text { Feelings of pressure from teachers who evaluate } \\
\text { students' performance by comparison }\end{array}$ & $5.3 \%$ & $14.9 \%$ & $36.8 \%$ & $35.1 \%$ & $7.9 \%$ \\
\hline $\begin{array}{l}\text { Feelings that clinical practice affects involvement } \\
\text { in extracurricular activities }\end{array}$ & $5.3 \%$ & $14.0 \%$ & $45.6 \%$ & $28.1 \%$ & $7.0 \%$ \\
\hline Inability to get along with group peers & $5.3 \%$ & $21.9 \%$ & $45.6 \%$ & $15.8 \%$ & $11.4 \%$ \\
\hline
\end{tabular}

\section{Table: 5}

Nursing Students Responses to Stress

\begin{tabular}{|l|l|c|c|c|c|c|}
\hline $\begin{array}{l}\text { S. } \\
\text { No }\end{array}$ & Statement & Never & $\begin{array}{c}\text { Almost } \\
\text { never }\end{array}$ & Sometimes & $\begin{array}{c}\text { Fairly } \\
\text { often }\end{array}$ & $\begin{array}{c}\text { Very } \\
\text { often }\end{array}$ \\
\hline & I. Emotional symptoms & & & & & \\
\hline & I tend to be worried and nervous & $13.2 \%$ & $7.9 \%$ & $47.4 \%$ & $18.4 \%$ & $13.2 \%$ \\
\hline & I tend to be nervous and anxious lately & $9.6 \%$ & $19.3 \%$ & $35.1 \%$ & $21.9 \%$ & $14.0 \%$ \\
\hline & I often feel depressed and miserable & $7.0 \%$ & $14.0 \%$ & $38.6 \%$ & $30.7 \%$ & $9.6 \%$ \\
\hline & I feel afraid without any reason & $14.9 \%$ & $13.2 \%$ & $28.9 \%$ & $28.1 \%$ & $14.9 \%$ \\
\hline $\begin{array}{l}\text { I feel I am going to have a nervous } \\
\text { breakdown }\end{array}$ & $15.8 \%$ & $18.4 \%$ & $36.8 \%$ & $15.8 \%$ & $13.2 \%$ \\
\hline & I feel more anxious lately & $15.8 \%$ & $18.4 \%$ & $33.3 \%$ & $22.8 \%$ & $9.6 \%$ \\
\hline & I cannot calm down & $14.0 \%$ & $14.9 \%$ & $29.8 \%$ & $29.8 \%$ & $11.4 \%$ \\
\hline & II. Social behavioral symptoms & & & & \\
\hline & I am not optimistic about my future & $16.7 \%$ & $14.0 \%$ & $33.3 \%$ & $23.7 \%$ & $12.3 \%$ \\
\hline & My life is not very colorful & $19.3 \%$ & $16.7 \%$ & $28.9 \%$ & $24.6 \%$ & $10.5 \%$ \\
\hline & I cannot work as usual & $13.2 \%$ & $24.6 \%$ & $31.6 \%$ & $19.3 \%$ & $11.4 \%$ \\
\hline & I have difficulty in making decisions & $10.5 \%$ & $14.9 \%$ & $37.7 \%$ & $21.1 \%$ & $15.8 \%$ \\
\hline & I do not feel needed or valued & $13.2 \%$ & $19.3 \%$ & $35.1 \%$ & $19.3 \%$ & $13.2 \%$ \\
\hline & $\begin{array}{l}\text { I cannot think as clearly as } \\
\text { before }\end{array}$ & $9.6 \%$ & $19.3 \%$ & $37.7 \%$ & $22.8 \%$ & $10.5 \%$ \\
\hline & III. Physical symptoms & & & & & \\
\hline & I often feel giddy & $10.5 \%$ & $15.8 \%$ & $42.1 \%$ & $21.9 \%$ & $9.6 \%$ \\
\hline & I experience nausea and vomiting & $14.0 \%$ & $10.5 \%$ & $42.1 \%$ & $24.6 \%$ & $8.8 \%$ \\
\hline & I often have vertigo and feel dizzy & $11.4 \%$ & $15.8 \%$ & $41.2 \%$ & $20.2 \%$ & $11.4 \%$ \\
\hline & I feel pressure in the chest & $16.7 \%$ & $23.7 \%$ & $33.3 \%$ & $14.0 \%$ & $12.3 \%$ \\
\hline & My fingers and toes feel numb or painful & $14.9 \%$ & $17.5 \%$ & $33.3 \%$ & $21.1 \%$ & $13.2 \%$ \\
\hline & I have stomach-ache and diarrhea & $21.1 \%$ & $14.9 \%$ & $30.7 \%$ & $19.3 \%$ & $14.0 \%$ \\
\hline & $\begin{array}{l}\text { I have difficulties in breathing for no } \\
\text { reason }\end{array}$ & $16.7 \%$ & $18.4 \%$ & $36.8 \%$ & $14.9 \%$ & $13.2 \%$ \\
\hline & I catch cold more often & $14.6 \%$ & $12.3 \%$ & $36.8 \%$ & $21.1 \%$ & $15.8 \%$ \\
\hline Above & & & & \\
\hline
\end{tabular}

Above tables shows the results of overall respondent in form of percentage 
Section: 3

Table: 6

\begin{tabular}{|c|c|c|c|}
\hline \multicolumn{4}{|c|}{ Correlations between PSS Scale and PPSRS Scale } \\
\hline & & PSS Variables & PPSRS Variables \\
\hline \multirow[t]{3}{*}{ PSS Variables } & Pearson Correlation & 1 & $.594^{* *}$ \\
\hline & Sig. (2-tailed) & & .000 \\
\hline & $\mathrm{N}$ & 114 & 114 \\
\hline \multirow[t]{3}{*}{ PPSRS Variables } & Pearson Correlation & $.594^{* *}$ & 1 \\
\hline & Sig. (2-tailed) & .000 & \\
\hline & $\mathrm{N}$ & 114 & 114 \\
\hline
\end{tabular}

Table shows the significant correlation between the level of stress and stress response in students. Pearson correlation value is .594 and $\mathrm{p}$ value is .000 on 0.05 level of confidence interval which shows significance of results.

\begin{tabular}{|c|c|c|c|c|c|c|c|c|c|c|}
\hline & & Table: 7 & Correlation & is betwe & en sub scal & es of PS & and I & PSRS & & \\
\hline & & $\begin{array}{l}\text { Stress from } \\
\text { lack of } \\
\text { professional } \\
\text { knowledge and } \\
\text { skills }\end{array}$ & $\begin{array}{l}\text { Stress from } \\
\text { assignment } \\
\text { and workload }\end{array}$ & $\begin{array}{l}\text { Stress } \\
\text { from } \\
\text { taking } \\
\text { care of } \\
\text { patients }\end{array}$ & $\begin{array}{l}\text { Stress from } \\
\text { clinical } \\
\text { environment }\end{array}$ & $\begin{array}{l}\text { Stress } \\
\text { from } \\
\text { teachers } \\
\text { and } \\
\text { nursing } \\
\text { staff }\end{array}$ & $\begin{array}{l}\text { Stress } \\
\text { from } \\
\text { peers } \\
\text { and } \\
\text { daily } \\
\text { life }\end{array}$ & $\begin{array}{l}\text { Emotional } \\
\text { Symptoms }\end{array}$ & $\begin{array}{l}\text { Social } \\
\text { behavioural } \\
\text { Symptoms }\end{array}$ & $\begin{array}{l}\text { Physical } \\
\text { Symptoms }\end{array}$ \\
\hline $\begin{array}{l}\text { Stress from lack } \\
\text { of professional }\end{array}$ & $\begin{array}{l}\text { Pearson } \\
\text { Correlation }\end{array}$ & 1 & $.278^{* *}$ & $.544^{* *}$ & $.412^{* *}$ & $.389^{* *}$ & $.232^{*}$ & $.412^{* *}$ & $.407^{* *}$ & $.269^{* *}$ \\
\hline $\begin{array}{l}\text { knowledge and } \\
\text { skills }\end{array}$ & \begin{tabular}{|l} 
Sig. (2- \\
tailed)
\end{tabular} & & .003 & .000 & .000 & .000 & .013 & .000 & .000 & .004 \\
\hline & $\bar{N}$ & 114 & 114 & 114 & 114 & 114 & 114 & 114 & 114 & 114 \\
\hline $\begin{array}{l}\text { Stress from } \\
\text { assignment and }\end{array}$ & $\begin{array}{l}\text { Pearson } \\
\text { Correlation }\end{array}$ & $.278^{* *}$ & 1 & $450^{* *}$ & $.396^{* *}$ & $.349^{* *}$ & $316^{* *}$ & $.286^{* *}$ & .109 & .178 \\
\hline workload & \begin{tabular}{|l} 
Sig. (2- \\
tailed)
\end{tabular} & .003 & & .000 & .000 & .000 & .001 & .002 & .248 & .058 \\
\hline & $\mathrm{N}$ & 114 & 114 & 114 & 114 & 114 & 114 & 114 & 114 & 114 \\
\hline $\begin{array}{l}\text { Stress from } \\
\text { taking care of }\end{array}$ & $\begin{array}{l}\text { Pearson } \\
\text { Correlation }\end{array}$ & $.544^{* *}$ & $.450^{* *}$ & 1 & $.639^{* *}$ & $.584^{* *}$ & $430^{* *}$ & $.526^{* *}$ & $.551^{* *}$ & $446^{* *}$ \\
\hline patients & $\begin{array}{l}\text { Sig. (2- } \\
\text { tailed) }\end{array}$ & .000 & .000 & & .000 & .000 & .000 & .000 & .000 & .000 \\
\hline & $\mathrm{N}$ & 114 & 114 & 114 & 114 & 114 & 114 & 114 & 114 & 114 \\
\hline $\begin{array}{l}\text { Stress from } \\
\text { clinical }\end{array}$ & $\begin{array}{l}\text { Pearson } \\
\text { Correlation }\end{array}$ & $.412^{* *}$ & $.396^{* *}$ & $.639^{* *}$ & 1 & $.574^{* *}$ & $485^{* *}$ & $.422^{* *}$ & $412^{* *}$ & $.343^{* *}$ \\
\hline environment & $\begin{array}{l}\text { Sig. (2- } \\
\text { tailed) }\end{array}$ & .000 & .000 & .000 & & .000 & .000 & .000 & .000 & .000 \\
\hline & $\mathrm{N}$ & 114 & 114 & 114 & 114 & 114 & 114 & 114 & 114 & 114 \\
\hline $\begin{array}{l}\text { Stress from } \\
\text { teachers and }\end{array}$ & $\begin{array}{l}\text { Pearson } \\
\text { Correlation }\end{array}$ & $389^{* *}$ & $.349^{* *}$ & $.584^{* *}$ & $.574^{* *}$ & 1 & $399^{* *}$ & $.370^{* *}$ & $.531^{* *}$ & $388^{* *}$ \\
\hline nursing staff & \begin{tabular}{|l} 
Sig. (2- \\
tailed)
\end{tabular} & .000 & .000 & .000 & .000 & & .000 & .000 & .000 & .000 \\
\hline & $\mathrm{N}$ & 114 & 114 & 114 & 114 & 114 & 114 & 114 & 114 & 114 \\
\hline $\begin{array}{l}\text { Stress from } \\
\text { peers and daily }\end{array}$ & $\begin{array}{l}\text { Pearson } \\
\text { Correlation }\end{array}$ & $.232^{*}$ & $316^{* *}$ & $.430^{* *}$ & $.485^{* *}$ & $.399^{* *}$ & 1 & $.392^{* *}$ & $.268^{* *}$ & $.207^{*}$ \\
\hline life & $\begin{array}{l}\text { Sig. (2- } \\
\text { tailed) }\end{array}$ & .013 & .001 & .000 & .000 & .000 & & .000 & .004 & .027 \\
\hline & $\mathrm{N}$ & 114 & 114 & 114 & 114 & 114 & 114 & 114 & 114 & 114 \\
\hline
\end{tabular}

Table 5 shows the overall correlation between subgroups of PSS and PPSRS.

Correlation between stress from lack of professional knowledge and emotional symptoms is significant with $\mathrm{r}=.412$ and $\mathrm{p}$ value .000 and relationship with social behavioral symptoms with $\mathrm{r}=.407$ and $\mathrm{p}$ value .000 and physiological symptoms with $\mathrm{r}=.269$ and $\mathrm{p}$ value .004 .Correlation between assignment and work load and emotional symptoms is significant with $(\mathrm{r}=.286, \mathrm{p}=.002)$, Relationship of stress of taking care of patient and emotional symptoms ( $\mathrm{r}=526 . \mathrm{p}=.000)$, social behavioral symptoms $(\mathrm{r}=.551, \mathrm{p}=.000)$,physiological symptoms $(\mathrm{r}=.446, \mathrm{p}=.000)$ is significant. Relationship is significant in stress from clinical learning environment and emotional symptoms $(r=.422, p=.000)$, social behavioral symptoms $(r=.412, p=.000)$, and physiological symptoms $(\mathrm{r}=.343, \mathrm{p}=.000)$. Significant correlation between stress due to discrimination of teachers and nursing staff and emotional symptoms $(\mathrm{r}=370, \mathrm{p}=.000)$, social behavioral symptoms $(\mathrm{r}=531, \mathrm{p}=.000)$ and physiological symptoms $(\mathrm{r}=388, \mathrm{p}=.000)$. Relationship between peer pressure and emotional symptoms $(\mathrm{r}=.392, \mathrm{p}=.000)$, social behavioral symptoms $(\mathrm{r}=268, \mathrm{p}=.004)$ is significant. Overall results show the significant correlation between stress level and responses of nursing student. In this examination, the apparent physio-psycho-social wellbeing in students is considered as great wellbeing. This could be a sign that student can adapt up to different stressors looked during 
their nursing training. Centre finding of this examination was the huge relationships between apparent dimensions of pressure and saw physio-psyho-social wellbeing. Students who see a larger amount of pressure were bound to have less fortunate physio-psycho-social wellbeing. This outcome is an attestation of the hypothesis by Lazarus and Folkman's (1984) (Admi, Moshe-Eilon, Sharon, \& Mann, 2018) that affirms that pressure can influence individuals' physical, mental and social wellbeing if adaptational results can't be accomplished. From these results alternative hypothesis is accepted that there is association between level of stress and to it responses.

\section{DISCUSSION}

This study explores the level of stress and physio-psycho-social responses to stress nurses in a government nursing institute. Result of this investigation has verified that perceived level of stress in student nurses was well-thoughtout as moderate stress. During nursing education, nursing students face stress which ranges from moderate to severe levels resulting from various stressors (Bahadır-Y1lmaz, 2016) Statistics shown that the most common type of stressor identified by students was stress from assignments and workload. As study indicated that the student nursing major stressor is assignment and workload and nursing students face higher stress than other students (Alzayyat, 2016). Moreover, student nurses are also stressed because of ventures, term papers, quizzes, and examinations from other non-nursing subjects making the program tough and ambiguous as compared to other programs. Additionally, nursing students are relied upon to extensive clinical arrangement hours, and are likewise required to finish an assortment of assignments, for example, case reports, nursing care plans, and relational recordings. The feelings of anxiety of finishing these exercises are known to be critical for the nursing understudies (Liu, Gu, Wong, Luo, \& Chan, 2015). In this study stress from lack of professional knowledge with the mean and

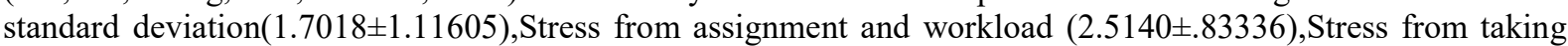

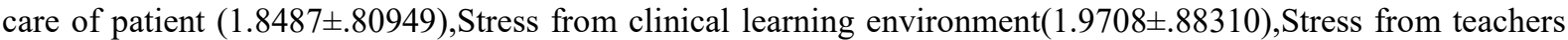

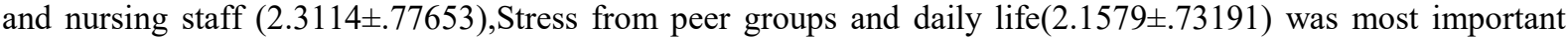
sources of stress in this study. These results of research supported by results of a study in which results showed stress from lack of professional knowledge and skills1.98 $\pm 1.06(\mathrm{p}<0.001)$, from assignments and workload $2.46 \pm 0.76$ stress from taking care of patients $1.74 \pm 0.88(\mathrm{p}<0.001)$, stress from clinical environment $2.07 \pm 0.90$ $(\mathrm{p}<0.018)$, stress from faculty and staff $2.24 \pm 0.76(\mathrm{p}<0.001)$, Stress from peers and daily life $2.02 \pm 0.85(\mathrm{p}<0.001)$ (Labrague, McEnroe-Petitte, et al., 2018). This study shows the significant correlation between perceived level of stress and physio-psycho-social health, results of the study supported by a research results showed that nursing students' pressure adapting levels were influenced without anyone else regard and social help. Also, this connection seems to influence general wellbeing status (Yıldırım, Karaca, Cangur, Acıkgoz, \& Akkus, 2017).Results revealed the significant correlation between different academic stress level and emotional, physiological and social responses of students, study supported by the research findings of Frank and Pulido which shows that academic stress can cause physiological and psychological stress which may develop mental disorder (Pulido-Criollo et al., 2017). Findings of this study demands for a bigger task for nurse professors in scheduling plans to avoid relapse of stress among students while keeping them inspired to achieve for a better education. The research suggest that coping behaviours or strategies can help the students to improve their health and to overcome their stress level, Enthusiastic insight did not direct adapting procedures in recently enlisted nursing students utilizing issue cantered adapting to address word related worry during the job time frame might be a defensive factor for adapting to worry in the working environment (Mazzella Ebstein et al., 2019).A study finding also revealed that positive correlation between coping strategies and nursing students stress (Al-Gamal, Alhosain, \& Alsunaye, 2018). Another study indicate the positive correlation between stress and coping strategies (Pun, Samson, \& Timalsina, 2018)

\section{CONCLUSION}

The correlational study was done in Government College of Nursing at Lahore. The study explores the level of stress in nursing students and their personal responses to stress in learning environment. It is concluded that if the stress level in nursing students reduce it can be helpful for the organization to improve the quality care of patient. The outcomes gave basic and valuable data to nurse instructors in distinguishing nursing students' needs, encouraging their learning both in the scholarly and clinical setting, and arranging powerful intercessions and systems to decrease or prevent stress in nursing education and training. Besides, nursing teachers must be keen of these stressors and ought to fortify understudies' adapting aptitudes to manage the distinctive stressors during nursing education and clinical setting.

\section{LIMITATIONS}

The study was done on small population due to limited time and concern. Students from other institution may provide generalizable data. Future studies recommended the adaptational strategies during nursing training which will be helpful for students in their learning environment. 


\section{ACKNOWLEDGEMENT}

I would like to acknowledge the people who guide me for this study. Firstly, I would like to show greatness Mr. Muhammad Afzal (The Principal of Lahore School of Nursing) who permitted me to done this study. I am extremely thankful to Sir Muhammad Hussain for being my preceptor to guide me in research work. I am thankful to all my participants their participation made my research meaningful. Their contribution made this study probable. It is a great preference to have all of these bright people in my life. I thank the administration of University of Lahore.

\section{REFERENCES}

Admi, H., Moshe-Eilon, Y., Sharon, D., \& Mann, M. (2018). Nursing students' stress and satisfaction in clinical practice along different stages: A cross-sectional study. Nurse education today, 68, 86-92.

Al-Gamal, E., Alhosain, A., \& Alsunaye, K. (2018). Stress and coping strategies among Saudi nursing students during clinical education. Perspectives in psychiatric care, 54(2), 198-205.

Alzayyat, A. (2016). Perceived stress and coping strategies among jordanian nursing students during clinical practice in psychiatric/mental health courses. European Psychiatry, 33, S190.

Bahadir-Y1lmaz, E. (2016). Academic and clinical stress, stress resources and ways of coping among Turkish firstyear nursing students in their first clinical practice. Kontakt, 18(3), e145-e151.

Elsayes, H. A., \& Obied, H. K. (2018). Association between senior nursing students' perceived stress and learning environment in clinical practice. Journal of Nursing Education and Practice, 8(3).

Hakami, D. A., Mahran, S. M., \& El-senany, S. A. (2017). Nursing Students' Perception to Stress during Clinical Training at King Abdulaziz University. Social Science Learning Education Journal, 2(11).

Ismaile, S. (2017). Perceived clinical stressors among Saudi nursing students. Open Journal of Nursing, 7(04), 463.

Jamshidi, N., Molazem, Z., Sharif, F., Torabizadeh, C., \& Najafi Kalyani, M. (2016). The challenges of nursing students in the clinical learning environment: A qualitative study. The Scientific World Journal, 2016.

Khamisa, N., Oldenburg, B., Peltzer, K., \& Ilic, D. (2015). Work related stress, burnout, job satisfaction and general health of nurses. International journal of environmental research and public health, 12(1), 652-666.

Labrague, L. J., McEnroe-Petitte, D. M., Papathanasiou, I. V., Edet, O. B., Tsaras, K., Leocadio, M. C., . . Rosales, R. A. (2018). Stress and coping strategies among nursing students: an international study. Journal of Mental Health, 27(5), 402-408.

Labrague, L. J., McEnroe-Petitte, D. M., Leocadio, M. C., Van Bogaert, P., \& Cummings, G. G. (2018). Stress and ways of coping among nurse managers: An integrative review. Journal of clinical nursing, 27(7-8), 13461359 .

Liu, M., Gu, K., Wong, T. K., Luo, M. Z., \& Chan, M. Y. (2015). Perceived stress among Macao nursing students in the clinical learning environment. International Journal of Nursing Sciences, 2(2), 128-133.

Mazzella Ebstein, A. M., Sanzero Eller, L., Tan, K. S., Cherniss, C., Ruggiero, J. S., \& Cimiotti, J. P. (2019). The relationships between coping, occupational stress, and emotional intelligence in newly hired oncology nurses. Psycho-Oncology, 28(2), 278-283.

Nirmala, V., \& Suni, M. (2016). Assertiveness, Self-esteem and Stress among Nursing Students. International Journal of Nursing Education, 8(1), 65-70.

Pålsson, Y., Engström, M., Leo Swenne, C., \& Mårtensson, G. (2018). A peer learning intervention targeting newly graduated nurses: A feasibility study with a descriptive design based on the Medical Research Council framework. Journal of advanced nursing, 74(5), 1127-1138.

Pulido-Criollo, F., Cueto-Escobedo, J., \& Guillén-Ruiz, G. (2017). Stress in Nursing University Students and Mental Health Health and Academic Achievement: IntechOpen.

Pun, K. M., Samson, P., \& Timalsina, R. (2018). Stress, stress responses and coping strategies among bachelor nursing students. Journal of Patan Academy of Health Sciences. 2018Dec, 5(2), 74-80.

Ramzan, S., Kousar, R., Chanda Jabeen, A. W., \& Gilani, S. A. (2017). The behaviors of clinical nursing faculty toward Student learning. Saudi Journal of Medical and Pharmaceutical Sciences. doi: 10.21276

Ratanasiripong, P., Park, J. F., Ratanasiripong, N., \& Kathalae, D. (2015). Stress and anxiety management in nursing students: Biofeedback and mindfulness meditation. Journal of Nursing Education, 54(9), 520-524.

Rathnayake, S., \& Ekanayaka, J. (2016). Depression, anxiety, and stress among undergraduate nursing students in a public university in Sri Lanka. International Journal of Caring Sciences, 9(3), 1020-1032.

Sarafis, P., Rousaki, E., Tsounis, A., Malliarou, M., Lahana, L., Bamidis, P., . . Papastavrou, E. (2016). The impact of occupational stress on nurses' caring behaviors and their health related quality of life. BMC nursing, 15(1), 56.

Taber, K. S. (2018). The use of Cronbach's alpha when developing and reporting research instruments in science education. Research in Science Education, 48(6), 1273-1296.

Umar, U. S. (2019). Impact of Academic Stress and Coping Strategies among Senior Secondary School Students 
in Kaduna State, Nigeria. International Journal of Innovative Social \& Science Education Research, 7(1), 4044.

Vijayananthan, S., Premkumar, J., Jesudoss, I., \& Rajan, A. (2016). Nursing students' perception of clinical experience. International Journal of Nursing Education, 8(1), 11-16.

Wallace, L., Bourke, M. P., Tormoehlen, L. J., \& Poe-Greskamp, M. V. (2015). Perceptions of clinical stress in baccalaureate nursing students. International journal of nursing education scholarship, 12(1), 91-98.

White, D. A. (2018). Faculty behaviors influencing intent to pursue graduate education among RN-BSN students. Teaching and Learning in Nursing, 13(2), 108-112.

Yıldırım, N., Karaca, A., Cangur, S., Acıkgoz, F., \& Akkus, D. (2017). The relationship between educational stress, stress coping, self-esteem, social support, and health status among nursing students in Turkey: A structural equation modeling approach. Nurse education today, 48, 33-39.

Zhao, F. F., Lei, X. L., He, W., Gu, Y. H., \& Li, D. W. (2015). The study of perceived stress, coping strategy and self-efficacy of $\mathrm{C}$ hinese undergraduate nursing students in clinical practice. International journal of nursing practice, 21(4), 401-409. 